\title{
Body Boundary Work: Praxeological Thoughts on Personal Corporality
}

\section{Tobias Boll $^{1}$ D $\cdot$ Sophie Merit Müller ${ }^{2}$}

Published online: 6 August 2020

(C) The Author(s) 2020

\begin{abstract}
In everyday life, we usually go by the one-body-one-person rule: one person has one body (and vice versa). This social belief builds on two assumptions: bodies are individual units and they (and 'their' person) are the same in different situations. This is also the conceptual resource for social theories that build on the notion of individuals. In this article, we turn it into a sociological topic. We develop a vocabulary for reconstructing bodily one-ness and bodily sameness as practically achieved social order, as body boundary work: what belongs to a body is a matter of local practices that define its situational contours, limits and margins. Practices of identification and personification draw on social memories and enact bodies as trans-situational entities. Persons and bodies, we argue, evolve in co-individuation. Personal corporality, then, can be conceptualized as a body of work that encompasses these practical efforts of boundary-making.
\end{abstract}

Keywords Body $\cdot$ Embodiment $\cdot$ Corporeality $\cdot$ Differentiation $\cdot$ Practice $\cdot$ Boundary work

\section{The One-Body-One-Person Rule}

In everyday encounters, bodies are addressed as persons, and persons become addressable, but also vulnerable as their bodies. People identify others based on their bodily appearance and manner (Goffman 1959: 14f.), and they identify themselves with what they experience as their own personal body (Crossley 1995). There

Tobias Boll

boll@uni-mainz.de

Sophie Merit Müller

sophie-merit.mueller@uni-tuebingen.de

1 Institute of Sociology, Johannes Gutenberg-University (JGU) Mainz, Jakob-Welder-Weg 12, 55128 Mainz, Germany

2 Institute of Sociology, Eberhard Karls University Tübingen, Wilhelmstraße 36, 72074 Tübingen, Germany 
is a fundamental social belief that a person has a body that is their body, and that there is one body per person (and vice versa). ${ }^{1}$ We call this the one-body-one-person rule. It builds on two assumptions. The first is the assumption of bodily oneness: commonly, a body is thought of as an individual entity circumscribed by the skin, which makes it an ideal vessel or 'material carrier' for an individual person. The second assumption is that of bodily and personal sameness. A person is usually understood as a biographical entity which moves between situations with their body, while both the person and their body stay essentially the same over time, independent from these contexts.

The commonplace, evident nature of this rule may be why it is also the baseline of social theories that take individuals as their starting point. While not sharing every aspect of the assumptions above, they build upon the idea of body-personunits, presupposing bodies as a basis for social individuals. Durkheim regarded the body as foundation for the process of social individuation (1968: 386). Mead (1934) built his theory around the idea of physical organisms that, through interaction, learn to regard themselves as selves. Following him, Strauss stated that the body was 'the medium through which conceptions of the self are formed' (1991: 345). Goffman's (1963a) interaction theory relies on bodies as permanent companions of persons, constantly displaying information about them. Bourdieu (1991: 26) described persons as 'biologically individualized bodies' whose social positions are shaped by their habitat in physical space. And, of course, the phenomenology of the body in the line of Plessner, Merleau-Ponty, or Sartre roots its methodological individualism in the corporeality of embodied selves (Crossley 1995).

Importing the one-body-one-person rule into the social sciences as an implicit presumption may seem unproblematic at first: it is socially paramount and unquestioned and consequently, many research topics, such as discrimination, interaction rituals or habitual dispositions, can be derived from this rule. Yet, adopting the one-body-one-person rule without having theorized it means, in Garfinkel's words, producing 'folk sociology' (Garfinkel 1967; see Zimmerman and Pollner 1971): the body-person-unit is then employed as a resource for research.

Turning it into a topic of research instead and deconstructing the one-body-oneperson-rule means providing body studies not only with a new field of empirical research topics, but also with a sociological foundation that then allows for legitimately taking body-person-units as (theoretically deconstructed) observation units whenever (and only when) this seems useful. To attempt this, however, it is useful to first look past the everyday plausibility of this rule. The field of body studies has strongly moved in this direction lately. As DiCaglio (2017: 5) observes, '[t]he question of the body's shifting boundaries [...] has been taken up repeatedly and with great attention'. Studies in this context have developed (mostly phenomenological) descriptions of empirical cases which unsettle the presumed unity of bodies and embodied selves. With their analyses of rather extraordinary cases like phantom limbs (Sobchack 2010) or facial transplants (Le Breton 2015) as well as comparatively mundane cases like pregnancy (Young 1984), they have 'radically undone' the

1 This belief is neither culturally nor historically universal (see Lindemann and Hyatt 2010: 285ff.). 
certainty of the body as 'the unified and fundamentally unchanging material base of continuing existence' (Shildrick 2010: 11). While the biological givenness of the body is challenged in this line of research, its phenomenological givenness for the experiencing self is still the basis of analysis. Whereas in this view, bodily experiences of the self are seen as the paramount process that constitutes corporality, in our view, they are just one of many processes that define what and where a body is. Furthermore, what remains unaddressed is the question how in everyday life, body boundaries and the coherence of embodied selves over time usually seem undramatic if not unproblematic. If we deconstruct the body as a unit theoretically, we also have to be able to explain how it holds together empirically and how it becomes self-evident as a unit in everyday life.

In this article, we address this as a problem that still awaits an adequate theoretical framework and vocabulary. Questioning the assumptions of bodily one-ness and bodily sameness, we ask: how can we socio-logically describe the body and personal corporality as everyday phenomena, in a way that does not draw on the assumption of their bio-logical and phenomeno-logical givenness and yet conceptually accounts for the social fact of the trans-situational corporality of a biographical person? We develop a praxeological concept of body boundary work, in an attempt to conceptually reconfigure the one-to-one-ness of bodies and persons as practically achieved social order. Our aim is to outline a systematic vocabulary that lives up to empirical complexity but contributes to social theory.

We first review practice theories that challenge essentialist notions of corporality and then turn to open questions of situational and trans-situational bodily coherence. To answer them, we apply the concept of boundary work to the body in two ways: first, we develop a notion of the body as situational boundary work. Second, we suggest that the trans-situational boundary work of ongoing personalization holds these situational bodies together as 'the' body of one specific biographical person. Personal bodies then appear as bodies of work which incorporate both kinds of body boundary work.

\section{Two Questions of Coherence}

Sociologists have widely conceived of the body in accordance with the everyday concept of a body, as a fleshy material thing that can learn, can be shaped and that hosts a self, for which it is its primary mode of being-in-the-world (Merleau-Ponty 1962) and anchor of identity (Mead 1934). As recent body studies have shown, this one-body-one-person rule does not always hold true empirically; informed by cases of precarious corporality, they have also emphatically questioned it theoretically (see, for example, Mol 2002; Shildrick 2010). What is still missing, however, is a systematic theoretical framework of personal corporality which can inform empirical reconstructions of the processes that stabilize bodies as coherent units and of the everyday practices that render personal bodies unproblematic matters of course. In order to develop such a framework, we employ a praxeological approach.

Practice theories empirically reconstruct the body relative to other sociological entities—knowledge, situations, or practices - to foster a decentered understanding 
of the body (and the individual actor). Foucault (1976) and others have shown that the body is relative to constellations of practices and discourses, to what is known about bodies. Drawing on a Foucaultian concept of the regulatory power of discourses, Butler (1993) has argued that the sexed body is a performative effect of discursive norms which materialize the body's sex in the first place. Approaches like these emphasize the relations between the materiality of the body and subjectivity. That has changed with methodological situationalism (Knorr-Cetina 1988). Here, the body is described as relational in regard to its engagement in situations. Depending on the specific practice the body is involved in, it is involved as something different. Conceptualized as a 'participand' (Hirschauer 2004), the body analytically differs from a person. In that framework, bodies are relative to what is practically made relevant about them. Along these lines, Alkemeyer and Michaeler have suggested the concept of a 'body-in-accomplishment' (Vollzugskörper) to describe how a body and its ability to participate in a practice are shaped and organized exclusively in course of the practice, as a body 'tuned' to its particular requirements (Alkemeyer and Michaeler 2013; Alkemeyer and Buschmann 2017). In this line of thought, a very important and influential contribution is the work of Annemarie Mol. She focuses on the ever-different practical production of bodies on a very fundamental, ontological level, speaking of the 'body multiple' (2002). In her praxiographic study of artherosclerosis, bodies, like the disease Mol studies, are entities enacted in local, situated practices (Mol and Law 2004). Instead of assuming a singular body being involved differently in diverse situations, Mol investigates how different and disparate versions of what 'a body' is are crafted in practice. ${ }^{2}$

Nevertheless, just like in other praxeological contributions the question of the body as an entity itself remains unasked and ethnographically untouched: when Mol (2002) follows atherosclerosis around a hospital, she describes in rich detail how the condition of the disease and, along with it, the body are brought about in multiple ways and localities. Yet, each of these practices takes a body for granted as an entity to work with, to measure or to feel. In her analysis, Mol takes this for granted as well, as she is interested in the multiple and varying versions of the disease, which imply different bodily phenomena, but not in the practical demarcation of 'the body' as a particular entity. But if a body is practically constructed, we have to reconstruct how-in practice-some things become part of this entity called a 'body' and others do not.

\footnotetext{
2 This decentered conception of bodies links up with other approaches in social theory that, as well, promote a less essentialist view. In postfeminist theory, concepts like 'cyborgs' (Haraway 1991), 'leaky bodies' (Shildrick 1997), or 'volatile bodies' (Grosz 1994) all point out an understanding of bodies as hybrid, without inherent or fixed boundaries and in a continual process of becoming. Along these lines, more recent developments in New Materialist theory continue to challenge the notion of 'the body' as an ontologically given and discrete unit (see Rogowska-Stangret 2017). The starting point and a common theme in the works of authors like Karen Barad or Erin Manning is the idea that in its original state, 'the body' is fundamentally entangled with the world in a relationship of 'intra-activity', from which it is only temporarily differentiated in performative 'agential cuts' (Barad 2003). Hence, it is seen as a constant process of 'bodying', 'not subject but verb' (Manning 2013: 29). Our thinking is informed by these theoretical contributions and their focus on de-ontologizing the body. While the vocabulary they offer helps to think of the body as processual and as practical achievement, it does, in our view, not lend itself to a detailed description and reconstruction of the empirical processes involved. Our aim is to build on these foundational insights and to offer a working vocabulary for this purpose.
} 
A second problem with approaches that focus on the conceptualization of bodies as decentered, distributed or multiple is that many situations rely on the same body coming back (to the hospital for medical treatments or to the gym to follow an exercise plan, for example). Furthermore, concepts like 'biography' or 'relationship' strongly work with the assumption of a personal body that stays the same over time. If we only consider the situational, practical enactment of bodies as the reality of corporality, some important sociological concepts can no longer be applied: developments over the course of life, the accumulation of practical knowledge, processes of illness, relationship histories - all these depend on the concept of an individual and their body.

This dilemma can be illustrated in reference to Law and Mol's (2004) analysis of persons with hypoglycemia. The authors convincingly point out that the biographical persons suffering from this disease are not only patients and bodies with diabetes, but they also appear in different situations in which their body is enacted differently (as the body of a sports-person, for example). Their empirical argument, however, is that there are tensions between different versions of bodies, and that these versions have to be coordinated: 'Keeping ourselves together is one of the tasks of life' (Law and Mol 2004: 57). To make this point, Law and Mol necessarily have to draw on the idea of $a$ body that maintains a basic coherence over diverse situations as a particular body of a particular patient. But how is this personal coherence achieved? If this question is not asked, writing about 'this' body/person in a strict sense contradicts and glosses over (Jefferson 1985) the notion of bodies as practically enacted and situationally multiple entities. In Law's and Mol's (and many other) descriptions, this problem remains unsolved.

In the following, we draw on these praxeological approaches and especially on the style of thinking as developed by Mol. Going beyond these achievements, however, two questions of bodily coherence and their connection are at stake in this article: how do bodies come to exist and to hold together as 'a body' in a given situation? And: how does a body achieve trans-situational unity as the body of a specific biographical person? Additionally, a conceptual bridge between these two aspects is needed to provide theoretical coherence: how can we talk about situations and their bodies (what 'bodies' are in various situations) and about a person and their body in a biographical perspective without having to shift sociological and ontological registers?

\section{Boundaries, Body Boundaries, and Body Boundary Work}

Everyday encounters rely on the double (situational and trans-situational) coherence of bodies and persons. ${ }^{3}$ There is seldom a reason to doubt or an occasion to question it. Thus, to de-familiarize this phenomenon, we ask our questions in a different vocabulary. We employ a heuristic of differentiation and boundary making to

\footnotetext{
3 In this article, we are concerned with reconstructing how coherence of the body is socially accomplished. The concept of the person is necessarily related to this. It has been deconstructed in a rich tradition of post-structuralist literature. In order to develop our vocabulary, we use the term 'person,' like the term 'body,' in a non-essentialist way: in our use, it refers to a social entity which is endowed with a biographical history and an assumption of identity over time, which are both constituted in processes of interaction (Goffman 1963b) and communication (Luhmann 1995).
} 
the question of coherence and address it as body boundary work. In talking about body boundaries, we latch on to the recent discussions in body studies and refuse to take bodies for granted as bounded units. Speaking of work prevents us from simply assuming the opposite theoretically and ignoring the fact that in everyday life, bodies are made into largely unproblematic units. Before we flesh out the concept, let us revisit its three components for clarification.

In sociology, 'boundary' has become a widely known concept with various meanings. Most notably, it is used to describe the (self-)differentiation of social groups and thus the cultural side of social closure (Lamont and Molnàr 2002). ${ }^{4}$ Scholars have used the concept of 'boundary' to show that differences are not given in cultural essences but are brought forth by efforts of differentiation. These processes are emphasized particularly in regard to ethnicity (Barth 1969; Wimmer 2008), professions (Gieryn 1983) or class (Lamont 1992). The notion of 'body boundaries' could be understood as an attempt to emphasize only that bodies are involved in the making of social boundaries. Our interest, however, is directed at the bodily boundaries which underlie such processes. When we speak of body boundaries, we apply the constructivist tone of 'boundary' to another fundamental social unit with the same rigorous deontologization applied to groups: the social individual and its personal corporality. Adapting the famous dictum of Barth (1969: 15), we are interested in how boundaries are drawn that define (individual) bodies by enclosing certain 'cultural stuff' as what a body is.

The notion of body boundaries calls to mind the biological concept of the organism-environment distinction. So far, this concept has been sociologized in two different ways. First, it has been implemented in sociological models as a metaphor of the social. In structural functionalism, the idea of systems is modeled after biological organisms separated from and yet dependent on an environment (Parsons 1951). Second, in the phenomenology of the body, it has been defined as the anthropological grounds for sociality (Plessner 2019/1928). ${ }^{5}$ We aim at a concept that poses a different question: how are bodily boundaries practically negotiated and constituted through sociality in mundane situations? Adding an empirical twist to the notion of body boundaries as brought up in recent body studies (Shildrick 2010: 13), we view the body as the never-finished, yet at each given moment completed result of local processes of differentiation. It is a situational, temporary and ontologically fluid entity that is demarcated in situational practices.

\footnotetext{
${ }^{4}$ Different notions of 'boundary' are commonly employed as a feature of objects shared and facilitating cooperation between different social worlds (Star and Griesemer 1989), or as the socio-historical limit to what kind of entities are part of sociality (Lindemann 2009).

${ }^{5}$ In Levels of Organic Life and the Human, Helmuth Plessner (2019/1928) distinguishes forms of being based on ways of boundary realization ('Grenzrealisierung'). His theory of positionality explains individualization as an anthropological condition, namely as a possible consequence of the excentric corporeal self experiencing its own existence through, and being individualized by, the perception of the self's own physical/material body.
} 
Our notion of body boundary work refers to these practices. It differs from the more common applications of the term in sociology: 'Boundary-work' (Gieryn 1983; Lamont 1992) or 'boundary-making' (Wimmer 2008) have been coined as terms to describe 'cognitive schemes' (Wimmer 2008: 975) or propositional 'typification systems' (Lamont and Molnàr 2002: 171). 'Work' in this context mainly refers to discursive efforts that perpetuate distinctions. Our endeavor, in contrast, can be understood as an ethnomethodologically inspired study of work (Garfinkel 1986): working out bodily boundaries is a complex situated practice of talking, tinkering with objects, placing and moving things around, or producing visual and textual documents. And whereas Lamont and Wimmer's conceptions tie differentiation to assignments of qualitative value, we seek to understand how differences in quality (the 'bodily' and the 'non-bodily') are instated.

In the following sections, we map out two kinds of body boundary work. The next section, "Situational Boundary Work: Demarcating Bodies," problematizes the body as a situational unit(y) and presents a way of reconstructing its bodily oneness through practices of demarcating its contours, limits, and margins. Given the observation that practices constitute not only bodies-in-general, but personalized, recognizable bodies, the following section, "Trans-situational Boundary Work: Coindividuation of Bodies and Persons," problematizes how bodily and personal transsituational sameness are fabricated with interactional, documentary, and biographical memories.

\section{Situational Boundary Work: Demarcating Bodies}

To unfold the concept of body boundary work, it helps to have examples to draw on. In favor of readability, we have constructed the fictional case of the Weisman family. The Weismans are not a real family under a fictional name, nor are they a composite case made up of different real families. Nevertheless, their story serves as a condensed source of quasi-empirical material, since they are quite busy with different kinds of boundary work when it comes to their bodies. Their story is constructed from very mundane everyday knowledge, anecdotal evidence, and of scientific studies on different body-related phenomena. As such it shall serve as a narrative thread for our conceptual considerations in the following sections.

As he does every morning, Mr. Weisman gets up at 06:30. Sleepily, he walks into the bathroom, still undressed. He grabs his glasses and puts them on, restoring his normal vision. As he started a new diet last month, he steps on the scalebefore breakfast, so that nothing smudges the measurement. He enters the number into the weight loss app recommended by the dietician, along with his dieting plan. Only after a minute does he realize that he did not relieve himself before weighing: indeed, without the extra fluid, he weighs a little less than yesterday. But still, way too much fat around his middle. When Mrs. Weisman steps onto the scale after him, she is rather pleased to see that the number has gone up somewhat. 'I think Billie is coming along quite well!,' she smiles, stroking her belly that has begun protruding quite a bit in the last few weeks. In the kitchen, she takes her folic acid pill along with her toast and juice while Mr. Weisman strictly follows dietary orders: fewer 
carbs, more protein, and no more than 50 grams of fat per day. One hour left before work. Mr. Weisman changes into his jogging clothes. Tying his shoes, he thinks about the marathon that he would like to run next year. Is he going to make it? And in what time? Later, jogging along the river, he can feel that this speed is the most that he can maintain at the moment: his heart is pumping, his right knee hurts a little. Ever since he had to get his knee ligament replaced in surgery, he has had problems when running for too long or without proper technique. He can still feel it later at work.

So far, we have claimed that what a body is, is a matter of situational, practical demarcations of its boundaries. As the Weismans move through their day, how are these boundaries drawn? In the story above, this varies greatly, since the Weismans are engaged in three very different empirical phenomena: dieting, pregnancy and sports (all set in a Western, medicalized context). So first of all, we see that body boundaries are realized in a variety of ways: in practices that range from touching (the pregnant belly), measuring (the body's weight), or commenting on the body as an object to more complex practices aiming at developing or 'pushing' bodily boundaries (as in Mr. Weisman's diet or his running practice) to material transformations of the body (through pregnancy or in surgery) or modifications involving objects (like glasses). The demarcations these practices establish are temporary and can be and might have been (re-)drawn differently under different circumstances. They, and the closure and boundedness of the body they imply, last as long as the practice stabilizing them.

What we can also see is that empirically, boundaries are not only drawn in different ways, but this also results in different kinds of boundaries. Depending on what is at stake in a particular practice, boundaries are conceived of, treated and 'done' differently, thus a more nuanced sociological terminology seems appropriate for describing them. ${ }^{6}$ We broadly distinguish three types of boundaries:

\section{Contours}

First, we conceive of boundaries as contours that define the body's shape, and concurrently its composition and substance. When boundaries are treated and made relevant as contours in practices, they divide what belongs to the body from everything else, thus specifying its materiality and surface. Consider Mr. Weisman's diet. He is engaged in the 'reflexive body technique' (Crossley 2005) of reducing the 'excessive' fat around his abdomen. When he considers the fat around his abdomen 'too much' he draws the contour of his body outside of where it should be. His

\footnotetext{
${ }^{6}$ In this article, we develop abstract terms that can be applied to a variety of practices from the point of view of a distanced observer who is interested in social theory. The participants may call things differently and experience them differently, and they might not agree with our way of 'putting things into words' (Hirschauer 2006), while we would not disagree with theirs and its ethnographic superiority. Since we aim at a vocabulary for comparative analysis, however, we cannot rely on members' language from the context of any single practice. Our terminology is not tied to members' propositional knowledge or perception (and does not claim to be) but tries to capture phenomena in a different language.
} 
jeans from last year mark the contours of his former body by letting him feel the difference.

\section{Limits}

Contours correspond with a second type of boundaries: in practically addressing functionality and capacity, limits are enacted that define what a body can and should be able to achieve and to endure. Mr. Weisman feels his bodily limits during his morning run, when his heart and knee start to ache. He prepares for his future marathon start by training and systematically acquiring muscles geared to running. Constantly measuring his progress, he expands his limits and overcomes bodily limitations. Apart from assessing and setting these limitations in the first place, this type of boundary work operates through the attributions of achievements and capabilities to 'the body' and its 'own' properties and capacities, or to things external to the body. When Mr. Weisman's running time is taken at the finish line, for instance, the contribution of the running shoe will not be subtracted from the measured time, while in elite professional sports, prosthetics may well be considered unfair enhancement and advantage (Tamari 2017). ${ }^{7}$

\section{Margins}

Thirdly, a body's margins are made relevant when the body's reach is at stake. Sounds, smells, or even substances emitting from the body have a different range than the one demarcated by its contours. Controlling bodily orifices, for example, means regulating this reach and thus confining corporeality. In the hospital, the margins of Mrs. Weisman's body will expand when she is giving birth: screams are audible through the doors of the labor room, fluids, excrement, and matter leave her body. Margins also define where and when a body is (or can be) present: while the afterbirth is removed with the medical waste, a lingering smell might expand a body beyond its contours or even permeate the hallways of a hospital ward.

So far, we have illustrated each kind of boundary with just one of our three examples dieting, pregnancy, and sports. But of course, We can identify these types of practices across different examples and empirical phenomena: bodily contours are, for example, also drawn in sports, when prosthetics are framed as 'technical devices' (Cornelius 2013) in sports regulations, which draws the contour of the body between the ('organic') body and the prosthetic, while in the perception of the runner, it may circumscribe them. During Mrs. Weisman's pregnancy, the contours of her body not only expand through several clothing sizes; she may also begin to see (and feel) it not only as her body, but as a vessel for another body that forms inside it (Young 1984), hence the perceived contour of her body no longer only runs around

\footnotetext{
7 The athlete Oscar Pistorius was threatened with exclusion from the Olympic Games on the basis of biomechanical tests: His high achievements were attributed to his prosthetic leg, not to his bodily abilities (Brüggemann et al. 2008).
} 
its 'outside'. Mrs. Weisman may start to enact the contour of the abdominal wall as a barrier to an 'inside' by putting her hands on the abdomen to sense kicks, or sonography (Draper 2002). Bodily limits become evident when Mrs. Weisman's body, and she herself, will be pushed to the limits of their pain tolerance during childbirth. For Mr. Weisman, bodily limits will not only be tested in sports, but also at the breakfast table, when he needs to discipline himself and control supposedly inherent urges of his body, like hunger or greed. A set limit of fat intake calculated by his dietitian and counting calories help Mr. Weisman to know when he has had 'enough' to eat.

Different kinds of boundaries come with further complications. Every time that contours are (re)drawn, limits are (re)set or margins are (re)evaluated, the parameters of body boundary work and the characteristics of bodies may shift. Whether a body's boundary is cut out with scissors, oozes as drying blood under a band aid or dissipates slowly as a smell changes the type of boundary. This also changes boundary characteristics: depending on the particular circumstances, body boundaries can be clean cut and stable (like the athlete's body once the prosthetic is fit properly and fully functioning), but they can also be ambiguous and fuzzy or leaky (like the mother's lactating breasts), or even fluctuating (like the limits of performance during a sprint). With the methods of demarcation and the characteristics of the boundaries, the parameters of boundary work vary. These parameters can be as varied and manifold as cases of body boundary work are. Without attempting to provide an exhaustive list, we propose to distinguish at least the following three parameters:

\section{Forms of Belonging}

Drawing boundaries is making distinctions. Body boundary work distinguishes what belongs to the body from what does not. As in the examples above, various things can 'belong' to the body, depending on the specific practical circumstances. Yet, the way in which they belong varies. We might say that being part of the body is a question of composition. A body in a given situation may consist of more or less than what is enveloped by its skin. It may be an assembly of various entities that work together in a certain way, each playing their part (such as the jogging shoe and the muscles). But it may also consist of less: when Mrs. Weisman is in labor, her midwife may inform her about the opening of her cervix, but neither of them is situationally concerned with her toenails (which, biologically speaking, are also there). Of the various things that are part of a body, some may be considered as belonging to the body. Whether something belongs to the body or not is a question of categorization, and often a normative one. While Mr. Weisman may use special footwear developed to enhance his grip and acceleration on the ground, he does not consider taking steroids or amphetamines to heighten his performance, since sports organizations classify these as illegitimate additions and alterations to the body (IAAF 2015; Gaillard et al. 2000)—unlike his transplanted new knee ligament, which has become part of 'his' body. And while the fat cells and tissue around Mr. Weisman's mid-section may be under his skin, they do not belong to the body he wants to be. Finally, belonging in the body is a (normative) question of localization: some things have 
their 'right(-ful)' place 'inside' the body's boundaries. During pregnancy, the fetus may not be part of the mother's perceived body at first, then becomes part of it as the mother learns of its existence. She may or may still not consider it as belonging to her. If she does, she will probably hope that the embryo stays inside her body, especially during the first few weeks. A few months later, it is 'normal' for the fetus to leave her womb, thereby becoming a baby. This example leads to another parameter of body boundary work: time.

\section{Temporal Scopes}

The largest temporal scope of bodies is commonly called the 'life(-time)'. Life is the timespan within which the temporality of bodies is understood, evaluated and enacted in smaller time frames (like situations). Those evaluations usually refer to durations and include ideas about how long bodies' boundaries should be stable, how long they can be expected to stay intact, and how long certain things are part of these bodies. For example, we might think of the foot as a permanent and essential part of the body, while the jogging shoe might be seen as merely temporally part of the runner's body. The same goes for things like food or fluids, which are supposed to pass through the body (i.e. to only accidentally belong to it, which is why Mr. Weisman relieves himself of them before stepping on the scale), while also partly being digested into it and partly becoming something abjected. These ideas about how long something should be part of the body are the backdrop against which events like vomiting, constipation, or 'losing' a limb (or a child) are understood as crises.

\section{Ontological Registers}

Ontological registers set the system of relevance for further determinations of bodily boundaries. They encompass, first of all, conceptions of bodiliness. The running body is mainly a neuromuscular, functional body. The dieting body, on the contrary, is an eating body that, as a converter and transformer, does not have clean-cut boundaries (Mol 2008). The pregnant body is inherently creative in that it grows something new. At the same time, different criteria for bodiliness may be applied: boundaries are drawn, for instance, under the criteria of aliveness ('the prosthetic is mechanical and therefore not a body part'), functionality ('it makes me be able to run again'), or physical attachment (under which a wart may fall more within the boundaries than a severed leg). In some situations, these registers might be propositionally discussed. In others, they may be practically realized.

If we look at bodies from this perspective, new empirical questions arise: how are body boundaries worked out in particular practices, and what are their specifics? How does this affect the status of things that enter and exit the body, and the construction of a body's 'inside' and 'outside'? How is the belonging (to the body) of material and immaterial entities practically negotiated and how are they attached to and detached from the body? How are ontological differences between the 'bodily' and 'non-bodily' accentuated or blurred across different entities and materialities? 


\section{Trans-situational Boundary Work: Co-individuation of Bodies and Persons}

We could now try these analytical tools out in empirical situations. We might, for example, follow Mr. Weisman around during his day and see how his body is brought about in different situated practices. So far, however, we have just presupposed that there is a 'Mr. Weisman' with 'his' body whom we can follow around as an observational unit in our fictional case. In Mol's terms, we could say that Mr. Weisman's corporality is 'an intricately coordinated crowd: [a] body multiple' (Mol 2002: viii), as he appears in different situations. But this description would not provide us with a conceptual idea of how it becomes, in the end, $a$ body of $a$ particular person-Mr. Weisman. We need conceptual tools for asking how it is done that these bodies become stable as a particular body that stays the same over time. These processes are the second kind of boundary work.

Let us accompany Mrs. Weisman into the consulting room for her pregnancy check-up. Looking up from the patient information on her screen, the doctor gets up from her chair. 'Good morning Mrs. Weisman, how have you been?' Mrs. Weisman tells the doctor that she has been feeling her body changing radically in the last few weeks. 'Well, let's have a look and make sure everything is in order,' the doctor replies while signaling Mrs. Weisman to recline on the examination chair. After the sonogram, she measures Mrs. Weisman's belly, makes some entries in the maternity $\log$ and puts the new sonographic picture next to the last one. 'The baby has grown a lot since you were last here, but that's perfectly normal,' she says and points to a poster displaying the stages of fetal development.

When the doctor examines Mrs. Weisman, she takes for granted that she palpates, measures, and ultrasound-scans the same body as some weeks earlier, while at the same time noting 'perfectly normal' differences. Nevertheless, she does not doubt for a second that it is indeed still Mrs. Weisman she examines. What we can observe not only in this short fictional scene, but also in many other situations, is a very mundane fact: bodies are recognized - not only as themselves, but also as a particular person. We suggest that the sameness of the body over time and its identification as a 'person' are accomplished in two ways: tagging, which allows for trans-situational comparability, and the emphasis of similarity in these comparisons.

\section{Tagging}

First, shortly after or even before birth, something demarcated as a 'human body' becomes a someone. It is observed as such and thus individualized and personalized, e.g. tagged with a name. The newborn body in Mrs. Weisman's arms is the same 'Billie' she referred to when stepping off the scale. And because this body is 'Billie Weisman' now, the differences between its shape today and in five years will be observed as 'changes' and will be tracked as 'development'. By repeatedly addressing a body as 'Billie Weisman' in very different situational contexts and over time, it is made into a consistent trans-situational entity. Some body parts play more prominent roles here than others: while the tag is prominently attached to the face 
(on an ID card, for example), haircuts and leg shapes are less personalized. Conveniently enough, the person can also be trained to use the tag as self-reference: when Mr. Weisman first meets his future wife at a formal dinner with work colleagues, he introduces the present well-dressed, clean-shaven and yet somewhat bulky body with 'Hi, I'm Harry'. And when Mrs. Weisman sees him at the next conference, he will not be just any body, even though meanwhile, Mr. Weisman has lost some weight and has grown a mustache.

\section{Emphasis of Similarity}

Second, under the premise of the individualizing tag, bodies are treated with a relatively high tolerance for change, and they are even expected to change over the course of life. In interactions, continuities are emphasized while discontinuities are integrated into the picture. Everyday knowledge is prepared for Mrs. Weisman's son Billie to first be barely recognizable on the ultrasound picture, be born as a tiny thing with a disproportionally large head and then-'You've grown so much!'appear in different heights and shapes over the years. Later on, Billie notices in the mirror that his face now sprouts a beard, and wonders whether he should start shaving or not. But it does not cross his mind that it might not be his body he is looking at. The assumption of coherence-in-change is, of course, also undergirded with discursive knowledge, such as biology: the 'aging rates' of cells, organs and human organisms are measured, compared, related and fed back into our everyday knowledge. Also, change tolerance is not the same for different body parts: radically changed facial features from one day to the next due to surgery (Le Breton 2015) are more of a problem than a belly size changing over several months. So, for a human body, staying 'the same' means changing constantly within expected parameters. Body appearances and experiences are compared to those of previous situations and categorized as belonging to a particular person, employing a kind of if-can test: as in membership categorization (Sacks 1972: 332-335), bodies are recognized as a certain person until proven otherwise. At the same time, a 'person' as a particular, consistent unit is only identified by certain bodily features that are classified as 'identical' with a previously encountered and tagged appearance.

\section{Social Memories}

The practices of identification that rely on tagging and the emphasis of similarities need social and material infrastructure. Drawing on a concept by Hirschauer (1994: 683f.), we suggest that the fundamental same-ness of a personal body is, similar to a person's gender, embedded in social memories: even though the boundaries of a 'body' might be worked out in very different ways in different situations, over time boundary work creates certain self-restrictions for future boundary work. Situations do not only encompass the present, but also knowledge about the past and the absent, narrowing down the contingency of possible events (Goffman 1986). We distinguish three memories that guard the boundaries of one particular, personal body. They differ in their particular form of sociality. First, interactional memory: as we have seen 
in regard to Mrs. Weisman in the consulting room, as well as in regard to Harry's new acquaintance with her as a young adult, a person-body-connection is stabilized in the act of others reenacting a body as the same body and-in doing so-as a particular person. Moreover, this recognition as a practice is stored in the memory of interactions: rules of politeness and interaction rituals like greetings (Goffman 1967) repeatedly invoke identifications of persons with the body present in situations. Second, documentary memory: material artifacts like passports, sports records, or Mrs. Weisman's maternity log and her patient record tie certain bodily features to a name and provide the infrastructure for their stable, trans-situational identity and identification. They are used in different practices where they are actively related to bodies and persons, and they can also travel between situations. Third, biographical memory: ultimately, selves experience themselves as embodied (as the phenomenology of the body has pointed out) and their particular embodiment as a historical process. In the recollections of a biographical self, one has always been this body and it has been the same body all along. A self's memory consists of a constant stream of events, and their body appears as a stable entity that has moved through these events.

Building on these memories, practices of identification emerge that restrict future boundary work to work on a particular body. What can we conclude from this? We claimed earlier in this article that sociology usually takes 'the body' as the basis for the (social construction of an) individual person. Looking at it from a boundary work perspective, however, a person having an assumed life-long consistent identity is also crucial for the individuation of a particular and trans-situationally consistent human body. The individuation of bodies and biographical persons does not follow a strict one-way logic. Bodies and persons are entangled in co-individuation. They become trans-situational social individuals together-both function as the anchor for the individuation of the other and are tied to each other in constant work.

From here, a new field of empirical questions opens: how exactly are bodily biographies built in particular contexts? What kinds of identification practices are crucial to particular forms of relationships or settings? How do different social memories interfere or clash?

\section{Mr. Weisman's Body of Work}

A specific concept of personal corporality follows from these praxeological deconstructions. Looking back to Mr. Weisman's body, we might say that it is not one coherent body moving through different situations in time, but rather a 'body of work': it consists of the situational and trans-situational boundary work, which form its ever-evolving spatiotemporal definition.

In every situation, the boundaries of 'Mr. Weisman's body' are demarcated in a particular way at a particular site. In their combination (and even in their contradictions), they encompass where and when Mr. Weisman's body is. Some sites and practices are recurring: whenever Mr. Weisman puts on his jogging shoesthree times a week-he works on the (somewhat) same bodily contours as the 
last time. But something else happens during jogging. Limits are pushed and sometimes transgressed. A knee ligament snaps. So, Mr. Weisman has to go to the hospital where, with different methods, instruments and conceptions different boundary work is done that is only necessary because of the jogging. Situational boundary work is local, but the enacted boundaries not always are. They overlap, they interlace.

This is a result of the second kind of body boundary work that stabilizes something as 'Mr. Weisman's body'. The stabilizing practices that bind together body and person as a trans-situational entity. Nevertheless, even though the outcome of this kind of boundary work might be trans-situational, it is accomplished in local efforts: the sonogram shown around ('This is Billie!'), the clerk placing a photo on the new passport for Mr. Weisman, the technician forging a customized pair of glasses for him and-later, after his knee deteriorated further-another technician forging a prosthesis so that Mr. Weisman can continue to do his long distance running-all of these situations enact a particular, consistently changing, personalized body. A body of work, then, encompasses all these situational efforts.

\section{Conclusion}

At the beginning of this article, we identified the one-body-one-person rule as a basic assumption not only in everyday life, but also in social theories. We set out to look beyond this rule and to find ways to look at bodily one-ness and same-ness of individualized, personal bodies differently, for there were two issues at stake. One, importing that rule as a scientific concept without problematizing it means doing folk sociology (Garfinkel 1967), yet deconstructing it theoretically does not explain its empirical everyday plausibility. Two, even approaches that develop a different, praxeological view on the body do not problematize how bodies become demarcated as situational entities in the first place and how they then also stay 'the same' transsituationally; they have to draw on the idea of 'a' person and 'their' body in order to describe their cases.

To offer conceptual tools that can help solve these problems, we unraveled two kinds of boundary work: first, situational body boundary work draws contours, limits and margins that separate a body from other (co-emerging) entities. Second, trans-situational body boundary work renders a particular body coherent over time by drawing on interactional, documentary and biographical memories, establishing persons and their bodies in co-individuation. We suggested to understand personal corporeality as a body of work that incorporates these two kinds of body boundary work and allows to ask questions relating to both situational and trans-situational corporeality from a praxeological perspective. Looking beyond the one-person-onebody rule and exchanging it for the notion of body boundary work allows to relate to embodied, biographical persons as observation units without re-centering them or their body theoretically. New empirical questions arise from this conceptional angle, as we have highlighted throughout this article with regards to situational and trans-situational boundary work. Moreover, the concept opens up new analytical complexities and complications. In doing so, it also allows for new analytical 
angles on different existing research topics and areas. One example of how our conceptual thoughts and vocabulary could prove to be useful in this way are studies in 'human categorization' (Hirschauer 2020). The concept might be used to reconstruct body-related social types and categories as configurations of body boundary work, asking how they relate to questions of inequality and discrimination, power asymmetries or social conflict. How do body concepts and normativities (like the malleable, 'healthy,' 'able,' morbid or trainable body) correspond to typical kinds of body boundary work? How does the categorization of persons (in regard to race, gender or dis/ability, for example) rely on their bodily sameness, and how is (dis-)continuity fabricated (such as in cases of sex change)?

Instead of drawing a final conclusion, then, we express our hope that the concept and vocabulary we have developed in this article will contribute to empirical research-which in turn can then challenge and sharpen this concept of personal corporality.

Acknowledgements Open Access funding provided by Projekt DEAL. The authors wish to thank the anonymous reviewers for their valuable comments and critique as well as all readers of earlier versions of this manuscript for helpful discussions. Among them are participants of the colloquium "Practice Research" and of our seminar "The Body and Its Boundaries" at Mainz University, with whom we had thought-provoking exchanges about the main topics of this article. Finally, we would like to thank Annemarie Mol for the opportunity to present and discuss our work during the "Body Boundary Workshop" at Amsterdam University and everyone who contributed.

Open Access This article is licensed under a Creative Commons Attribution 4.0 International License, which permits use, sharing, adaptation, distribution and reproduction in any medium or format, as long as you give appropriate credit to the original author(s) and the source, provide a link to the Creative Commons licence, and indicate if changes were made. The images or other third party material in this article are included in the article's Creative Commons licence, unless indicated otherwise in a credit line to the material. If material is not included in the article's Creative Commons licence and your intended use is not permitted by statutory regulation or exceeds the permitted use, you will need to obtain permission directly from the copyright holder. To view a copy of this licence, visit http://creativecommons.org/licen ses/by/4.0\%.

\section{References}

Alkemeyer, T., \& Buschmann, N. (2017). Learning in and across practices. Enablement as subjectivation. In A. Hui (Ed.), The nexus of practices: Connections, constellations, practitioners (pp. 8-23). London: Routledge.

Alkemeyer, T., \& Michaeler, M. (2013). Die Ausformung mitspielfähiger,Vollzugskörper‘. Praxistheoretisch-empirische Überlegungen am Beispiel des Volleyballspiels (Shaping the, Vollzugskörper'(, tuned body") to participate in the game: Praxeological and empirical considerations based on the example of volleyball). Sport und Gesellschaft, 10(3), 213-239.

Barad, K. (2003). Posthumanist performativity: Toward an understanding of how matter comes to matter. Signs: Journal of Women in Culture and Society, 28(3), 801-831.

Barth, F. (1969). Introduction. In F. Barth (Ed.), Ethnic groups and boundaries: The social organization of culture difference (pp. 9-38). London: Allen \& Unwin.

Bourdieu, P. (1991). Physischer, sozialer und sozial angeeigneter Raum (Physical, social, and socially appropriated space). In M. Wentz (Ed.), Stadt-Räume (pp. 25-34). Frankfurt: Campus.

Brüggemann, G.-P., Arampatzis, A., Emrich, F., \& Potthast, W. (2008). Biomechanics of double transtibial amputee sprinting using dedicated sprinting prostheses. Sports Technology, 1(4-5), 220-227.

Butler, J. (1993). Bodies that matter. On the discursive limits of "sex". London: Routledge.

Cornelius, S. (2013). CAS 2008/A/1480 Pistorius v IAAF. In J. Anderson (Ed.), Leading cases in sports law (pp. 229-238). The Hague: T. M. C. Asser Press. 
Crossley, N. (1995). Merleau-Ponty, the elusive body and carnal sociology. Body \& Society, 1(1), $43-63$.

Crossley, N. (2005). Mapping reflexive body techniques: On body modification and Maintenence. Body \& Society, 11(1), 1-35.

DiCaglio, S. (2017). Staging embryos: Pregnancy, temporality and the history of the Carnegie stages of embryo development. Body \& Society, 23(2), 3-24.

Draper, J. (2002). 'It was a real good show': The ultrasound scan, fathers and the power of visual knowledge. Sociology of Health \& Illness, 24(6), 771-795.

Durkheim, É. (1968). Les Formes élémentaires de la vie religieuse. Paris: PUF.

Foucault, M. (1976). The birth of the clinic: An archaeology of medical perception. London: Tavistock.

Gaillard, Y., Vayssette, F., \& Pépin, G. (2000). Compared interest between hair analysis and urinalysis in doping controls. Forensic Science International, 107(1), 361-379.

Garfinkel, H. (1967). Studies in ethnomethodology. Englewood Cliffs: Prentice-Hall.

Garfinkel, H. (Ed.). (1986). Ethnomethodological studies of work. London: Routledge.

Gieryn, T. (1983). Boundary-work and the demarcation of science from non-science: Strains and interests in professional ideologies of scientists. American Sociological Review, 48(6), 781-795.

Goffman, E. (1959). The presentation of self in everyday life. New York: Doubleday.

Goffman, E. (1963a). Behavior in public places. Note on the social organization of gatherings. New York: Free Press of Glencoe.

Goffman, E. (1963b). Stigma. Englewood Cliffs, NJ: Prentice-Hall.

Goffman, E. (1967). Interaction rituals: Essays on face-to-face behavior. Garden City: Doubleday.

Goffman, E. (1986). Frame analysis: An essay on the organization of experience. Boston: Northeastern University Press.

Grosz, E. (1994). Volatile bodies: Towards a corporeal feminism. St Leonards: Allen and Unwin.

Haraway, D. J. (1991). Simians, cyborgs, and women: The reinvention of nature. New York: Routledge.

Hirschauer, S. (1994). Die soziale Fortpflanzung der Zweigeschlechtlichkeit (The social procreation of two sexes). Kölner Zeitschrift für Soziologie und Sozialpsychologie, 46(4), 668-692.

Hirschauer, S. (2004). Praktiken und ihre Körper. Über materielle Partizipanden des Tuns (Practices and Their Bodies. On Material Participants of Action). In: K. Hörning, \& J. Reuter (Eds.), Doing Culture. Neue Positionen zum Verhältnis von Kultur und sozialer Praxis (pp. 73-91). Bielefeld: Transcript.

Hirschauer, S. (2006). Putting things into words. Ethnographic description and the silence of the social. Human Studies, 29(4), 413-441.

Hirschauer, S. (2020). Un/doing differences. The contingency of social affiliations. In G. Pelillo-Hestermeyer \& L. Gaupp (Eds.), Diversity and otherness. Transcultural Insights into norms, practices and negotiations. Boston: De Gruyter.

IAAF International Association of Athletic Federations (2015). IAAF Competition Rules 2016-2017. Resource Document. https://www.iaaf.org/about-iaaf/documents/rules-regulations\#rules. Accessed 14 March 2017.

Jefferson, G. (1985). On the interactional unpackaging of a 'gloss'. Language in Society, 14(4), 435-466.

Knorr-Cetina, K. (1988). The micro-social order: Towards a reconception. In N. Fielding (Ed.), Actions and structure: Research methods and social theory (pp. 21-53). London: Sage.

Lamont, M. (1992). Money, morals and manners. The culture of the French and American upper-middle class. Chicago: University of Chicago Press.

Lamont, M., \& Molnár, V. (2002). The study of boundaries in the social sciences. Annual Review of Sociology, 28, 167-195.

Le Breton, D. (2015). From disfigurement to facial transplant identity insights. Body \& Society, 21(4), 3-23.

Lindemann, G. (2009). Das Soziale von seinen Grenzen her denken (Thinking the social from the perspective of its borders). Weilerswist: Velbrück Wissenschaft.

Lindemann, G., \& Hyatt, M. (2010). The lived human body from the perspective of the shared world (Mitwelt). The Journal of Speculative Philosophy, 24(3), 275-291.

Luhmann, N. (1995). Die form person (The form person). In N. Luhmann (Ed.), Soziologische Aufklärung (Vol. 6, pp. 137-148). Opladen: Westdeutscher Verlag.

Manning, E. (2013). Always more than one. Individuation's dance. Durham: Duke University Press.

Mead, G. H. (1934). Mind, self, and society: From the standpoint of a social behaviorist. Chicago: University of Chicago Press.

Merleau-Ponty, M. (1962). Phenomenology of perception. London: Routledge \& Kegan Paul.

Mol, A. (2002). The body multiple. Ontology in medical practice. Durham: Duke University Press.

Mol, A. (2008). I eat an apple. On theorizing subjectivities. Subjectivity, 22(1), 28-37. 
Mol, A., \& Law, J. (2004). Embodied action, enacted bodies. The example of hypoglycaemia. Body \& Society, 10(2-3), 43-62.

Parsons, T. (1951). The social system. Toronto: Collier-Macmillan.

Plessner, H. (2019/1928). Levels of Organic Life and the Human. An Introduction to Philosophical Anthropology. New York: Fordam University Press.

Rogowska-Stangret, M. (2017). Corpor(e)al cartographies of new materialism. Meeting the elsewhere halfway. The Minnesota Review, 88, 59-68.

Sacks, H. (1972). On the analyzability of stories by children. In J. Gumperz \& D. Hymes (Eds.), Directions in sociolinguistics (pp. 325-345). New York: Holt, Rinehard \& Winston.

Shildrick, M. (1997). Leaky bodies and boundaries: Feminism, postmodernism and (bio)ethics. London: Routledge.

Shildrick, M. (2010). Some reflections on the socio-cultural and bioscientific limits of bodily integrity. Body \& Society, 16(3), 11-22.

Sobchack, V. (2010). Living a 'Phantom Limb': On the phenomenology of bodily integrity. Body \& Society, 16(3), 51-67.

Star, S. L., \& Griesemer, J. (1989). Institutional ecology, translations and boundary objects: Amateurs and professionals in Berkeley's Museum of Vertebrate Zoology, 1907-39. Social Studies of Science, 19(3), 387-420.

Strauss, A. (1991). Creating sociological awareness. Collective images and symbolic representations. New Brunswick: Transaction Publishers.

Tamari, T. (2017). Body image and prosthetic aesthetics. Body \& Society, 23(2), 25-56.

Wimmer, A. (2008). The making and unmaking of ethnic boundaries: A multilevel process theory. American Journal of Sociology, 113, 970-1022.

Young, I. M. (1984). Pregnant embodiment: Subjectivity and alienation. Journal of Medicine and Philosophy, 9, 45-62.

Zimmerman, D., \& Pollner, M. (1971). The everyday world as a phenomenon. In J. Douglas (Ed.), Understanding everyday life: Towards a reconstruction of sociological knowledge (pp. 80-103). London: Routledge \& Kegan Paul.

Publisher's Note Springer Nature remains neutral with regard to jurisdictional claims in published maps and institutional affiliations. 